\title{
RESPONSES BY LUCERNE AND ASSOCIATED VOLUNTEER SPECIES TO APPLIED FERTILIZERS IN NORTH CANTERBURY
}

\section{R. C. STephen}

\author{
Department of Agriculture, Christchurch
}

\section{INTRODUCTION}

IN Canterbury lucerne is generally established in 7 in. rows, without companion species, by drilling inoculated lucerne seed with matured lime-reverted superphosphate into an adequately cultivated and limed seedbed (Anon, 1958). As the crop ages, other species establish voluntarily so that eventually a mixed association of lucerne and variable proportions of grasses, clovers and other herbs results (Blair, 1965). The point at which volunteer species establish in the lucerne crop varies, and, although many crops remain free from other species for several years, some become infested during their establishment phase (Allen, 1967). The establishment and persistence of volunteers in the lucerne crop are affected by a wide range of factors such as the occurrence of lucerne diseases and pests (Blair, 1968), the variety of lucerne sown (Lobb, 1969), harvest and grazing management (Keoghan, 1967; O'Connor and Vartha, 1968), and applications of fertilizers (Sewell, 1960; Stephen, 1964; Harris, et al., 1966).

For many years it has been considered that the regular annual application of fertilizers to the lucerne crop is a practice necessary for the maintenance of vigorous lucerne growth and the suppression of volunteer species (Ward, 1921; Sewell, 1960). However, more recently it has been suggested that applications of phosphatic fertilizer may be detrimental to the lucerne crop and should be either reduced or withheld (Harris and Lobb, 1964) and that lucerne may be topdressed out of existence (Lobb, 1967). This paper, which considers the question of the need to apply fertilizers -especially phosphatic fertilizer--to the lucerne crop, gives details of the effects of applied phosphatic, potassic and sulphatic fertilizers on the growth of five-year-old lucerne and associated volunteer species as observed in four fertilizer experiments put down as part of a project designed to establish the kinds and quantities of fertilizers needed to maintain prolonged and vigorous lucerne growth on northern Canterbury soils. 


\section{EXPERIMENTAL}

In these experiments, phosphatic, potassic and sulphatic fertilizers were applied annually in the late winter to crops of Wairau lucerne that had been established approximately twelve months when the initial experimental applications of fertilizers were made.

The experimental applications of fertilizers were made to plots having individual areas of 0.004 acre and set out in randomized blocks within factorial layouts. As a consequence of the experimental designs employed, each treatment considered in this paper was replicated at least 16 times.

"Quick test" analyses of soil samples taken prior to the laying down of each experiment indicated that the surface layers of topsoil on each site were weakly to slightly acid, contained adequate levels of calcium but rather low levels of available potassium and available phosphate (Table 1).

Throughout each growing season the experimental lucerne crops were not grazed but, at a suitable stage of growth, mown for hay. However, during periods of summer and autumn drought and the winter months when lucerne growth was minimal the experimental crops were occasionally grazed by sheep for short periods.

Initially the experimental lucerne crops were free from volunteer species. However, by the beginning of the fifth

\section{TABLE 1: “QUICK TEST" ANALYSES OF SOIL SAMPLES:}

\section{AUGUST 1965}

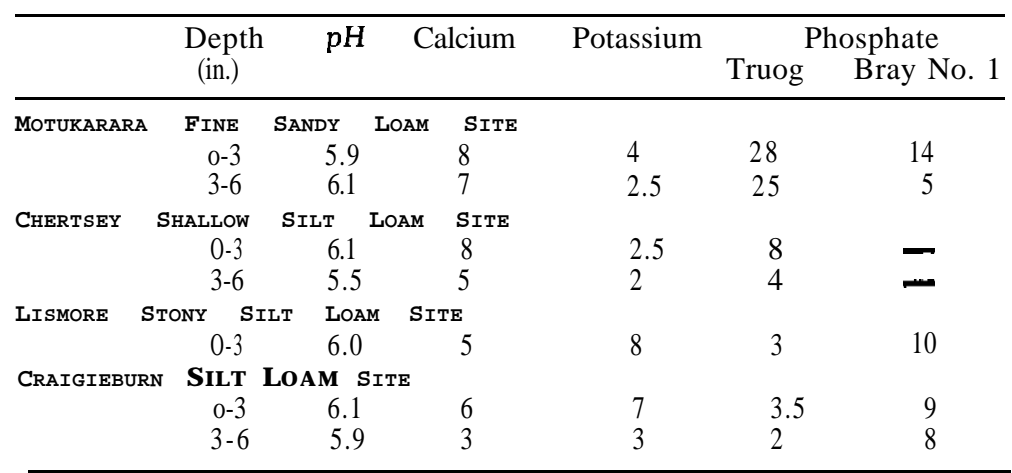

$\mathrm{pH}$ estimated in water suspension using a glass electrode.

Calcium expressed as parts $\mathrm{Ca}$ per 40,000 parts extract.

Truog phosphate expressed as parts $\mathrm{P}$ per $\mathbf{5 0 , 0 0 0 , 0 0 0}$ parts extract. Bray No. 1 phosphate expressed as parts $\mathrm{P}$ per 10,000,000 parts

extract. 
harvest season, other species were well established in each experimental lucerne crop.

\section{RESULTS}

\section{MOTUKarara Fine SANDY LOAM S ITE}

On a site on an area of Motukarara fine sandy loam, chickweed (Stellaria media (L.) Vill.) and some poa annua (Poa annua L.) established in the lucerne crop, and in the mild and damp winter and spring which preceded the fifth harvest season made vigorous growth until the onset of drier conditions at the time of the first hay cut. Following this cut, the lucerne made vigorous regrowth and although four further hay crops were taken the volunteer species made no further contribution to the total quantity of herbage produced in the late summer and autumn.

On this site, applications of potassic and sulphatic fertilizers had no real effects on the growth of lucerne and volunteer species, Phosphatic fertilizer caused significantly higher yields of lucerne and chickweed (Table 2).

\section{Chertsey Shallow Silt Loam Site}

On the experimental site on an area of Chertsey shallow silt loam, several annual species, vulpia hair grass (Vulpia spp.), suckling clover (Trifolium dubium Sibth.) and annual mouse-ear chickweed (Cerastium glomeratum Thuill.) established in the lucerne crop in its second year. By the fifth harvest season, these volunteers more or less filled the spaces between the Lucerne crowns on plots of

TABLE 2: YIELDS DRY MATTER (LB/ACRE) 1968-9 Motukarara fine sandy loam site

\begin{tabular}{|c|c|c|c|c|c|}
\hline & Lucerne & Grasses & Chickweed & $\begin{array}{c}\text { Other } \\
\text { Volunteers }\end{array}$ & Total \\
\hline \multicolumn{6}{|c|}{ Monocalcium phosphate } \\
\hline Nil & $\mathbf{7 , 7 9 0} \mathrm{bB}$ & 180 & $150 \mathrm{bB}$ & 150 & 8,270 bB \\
\hline 200 lb/acre & 11,490 aA & 110 & $380 \mathrm{aA}$ & 140 & $12,120 \mathrm{aA}$ \\
\hline \multicolumn{6}{|c|}{ Muriate of potash } \\
\hline Nil & 9,510 a & 170 & 270 a & 120 & 10,070 a \\
\hline 336 lb/acre & 9,830 a & 140 & 280 a & 80 & 10,330 a \\
\hline \multicolumn{6}{|c|}{ Calcium sulphate } \\
\hline Nil & 10,020 a & 170 & $340 \mathrm{a}$ & 70 & 10,600 a \\
\hline 362 lb/acre & 9,440 a & 140 & 260 a & 70 & 9,910 a \\
\hline $\mathbf{c} \mathbf{v}$ & $13 \%$ & NA & $64.9 \%$ & NA & $12.6 \%$ \\
\hline Interactions & n.s. & $\rightarrow$ & n.s. & - & n.s. \\
\hline
\end{tabular}


some fertilizer treatments. Vulpia hair grass and suckling clover were most densely established on areas not topdressed with phosphatic fertilizer. Annual mouse-ear chickweed was most common on areas treated with only phosphatic fertilizer.

In the fifth harvest season, when two hay crops were taken, vulpia hair grass, suckling clover and annual mouseear chickweed made no further growth after the harvest of the first hay crop.

On this site where phosphatic, potassic and sulphatic fertilizers caused significantly higher yields of lucerne, the response by lucerne to applied phosphatic fertilizer was almost twice as great as that to sulphatic fertilizer.

Sulphatic fertilizer had no effect on the growth of volunteer species, whereas phosphatic and potassic fertilizers caused significantly higher and lower yields, respectively, of volunteers other than grasses or clovers (Table 3).

TABLE 3: YIELDS DRY MATTER (LB/ACRE) 1968-9 Chertsey shallow silt loam site

\section{Lismore Stony Silt Loam Site}

In the third season following the establishment of the lucerne on the Lismore stony silt loam site, browntop (Agrostis tenuis Sibth.) and traces of white clover (Trifolium repens L.) established throughout the experimental crop. In the fifth harvest season when two hay crops were taken, browntop made little growth following the onset of 
late summer drought soon after the removal of the first hay cut.

On this site, applied phosphatic, potassic and sulphatic fertilizers caused higher yields of lucerne but had little effect on the growth of browntop and other volunteers. The lucerne yield response to phosphatic fertilizer was almost three times as great as those obtained from potassic or sulphatic fertilizers (Table 4). A higher total yield of lucerne and volunteer species was obtained where phosphatic and potassic fertilizers were applied together than where either was used alone.

\section{Craigieburn Silt Loam Site}

Brown\&p, sweet vernal (Anthoxanthum odoratum L.) , white clover, king devil (Hieracium praealtum Vill.) and other herbs established in the experimental crop almost as soon as the lucerne was drilled on the Craigieburn silt loam site. In the fifth harvest season, lucerne and the volunteer species made moderately vigorous growth throughout the late spring and summer. Two hay crops were taken before drought conditions limited further growth in the early autumn.

On this site lucerne gave significantly higher yields of herbage in the presence of phosphatic, potassic and sulphatic fertilizers. The lucerne response to applied sulphatic

TABLE 4: YIELDS DRY MATTER (LB/ACRE) 1968-9

Lismore stony silt loam site

\begin{tabular}{|c|c|c|c|c|c|}
\hline & Lucerne & Grasses & Clover & $\begin{array}{c}\text { Other } \\
\text { Volunteers }\end{array}$ & s Total \\
\hline \multicolumn{6}{|c|}{ Monocalcium phosphate } \\
\hline Nil & $800 \mathrm{bB}$ & $930 \mathrm{a}$ & 10 & 10 & $1,750 \mathrm{bB}$ \\
\hline $120 \mathrm{lb} / \mathrm{acre}$ & $1,700 \mathrm{aA}$ & $830 \mathrm{a}$ & 40 & 10 & 2,580 aA \\
\hline \multicolumn{6}{|c|}{ Muriate of potash } \\
\hline & $1,180 \mathrm{bB}$ & 970 a & 20 & 10 & $2,180 \mathrm{a}$ \\
\hline $336 \mathrm{lb} / \mathrm{acre}$ & $1,490 \mathrm{aA}$ & $850 a$ & 30 & 10 & $2,380 \mathrm{a}$ \\
\hline \multicolumn{6}{|c|}{ Calcium sulphate } \\
\hline Nil & $1,080 \mathrm{bB}$ & $940 \mathrm{a}$ & 30 & 10 & $2,060 \mathrm{bA}$ \\
\hline $218 \mathrm{lb} / \mathrm{acre}$ & $1,460 \mathrm{aA}$ & $800 \mathrm{a}$ & 30 & 10 & 2,300 aA \\
\hline $\mathrm{c} \mathrm{v}$ & $23.2 \%$ & 25.770 & NA & $\mathrm{NA}$ & $15.0 \%$ \\
\hline Interactions & n.s. & n.s. & - & - & $\underset{\mathrm{P} \times \mathrm{K}}{+}$ \\
\hline
\end{tabular}


fertilizer was twice as great as that obtained from potassic fertilizer and three times as great as that caused by the application of phosphatic fertilizer.

Apart from small changes in their proportions in the mixed herbage, the growth of volunteer grasses and clovers was not affected by applications of potassic and sulphatic fertilizers. Because of the more vigorous growth of white clover, phosphatic fertilizer caused a 50\% increase in the total herbage produced by volunteer species. Growth of volunteer grasses and other species was not affected by phosphatic fertilizer. The growth of volunteer species other than grasses and clovers was significantly reduced by applications of potassic and sulphatic fertilizers (Table $5)$.

TABLE 5: YIELDS DRY MATTER (LB/ACRE) 1968-9

Craigieburn silt loam site

\begin{tabular}{lccccc}
\hline & Lucerne & Grasses & Clover & $\begin{array}{c}\text { Other } \\
\text { Volunteers }\end{array}$ & Total \\
\hline Moniocalcium phosphate & $1,010 \mathrm{bA}$ & $300 \mathrm{a}$ & $440 \mathrm{bB}$ & $200 \mathrm{a}$ & $1,950 \mathrm{bB}$ \\
Nil & $1,430 \mathrm{aA}$ & $270 \mathrm{a}$ & $950 \mathrm{aA}$ & $160 \mathrm{a}$ & $2,810 \mathrm{aA}$ \\
$200 \mathrm{lb} / \mathrm{acre}$ & & & & & \\
Muriate of potash & & & & & \\
Nil : & $980 \mathrm{bB}$ & $310 \mathrm{a}$ & $740 \mathrm{a}$ & $190 \mathrm{aA}$ & $2,220 \mathrm{bB}$ \\
336 lb/acre & $1,670 \mathrm{aA}$ & $280 \mathrm{a}$ & $810 \mathrm{a}$ & $140 \mathrm{bB}$ & $2,900 \mathrm{aA}$ \\
Calcium sulphate & & & & & \\
Nil & $520 \mathrm{bB}$ & $230 \mathrm{a}$ & $610 \mathrm{a}$ & $210 \mathrm{aA}$ & $1,670 \mathrm{bB}$ \\
362 lb/acre & $1,840 \mathrm{aA}$ & $290 \mathrm{a}$ & $770 \mathrm{a}$ & $130 \mathrm{bB}$ & $3,030 \mathrm{aA}$ \\
CV & $39.0 \%$ & $31.8 \%$ & $32.2 \%$ & $35.7 \%$ & $21.5 \%$ \\
Interactions & + & n.s. & n.s. & n.s. & n.s. \\
& $\mathrm{K} \times \mathbf{S}$ & & & & \\
\hline
\end{tabular}

\section{DISCUSSION}

In these experiments, in spite of the better growth of some volunteer species, phosphatic fertilizer caused more vigorous growth and significantly higher yields of five-yearold lucerne established on each of four soils. Potassic and sulphatic fertilizers caused higher yields of five-year-old lucerne on the Chertsey, Lismore and Craigieburn soil sites. Growth and herbage yields of some volunteer species which were depressed on the Chertsey and Craigieburn soil sites by potassic fertilizer and on the Motukarara and Craigie- 
burn soil sites by sulphatic fertilizer, were favoured by applied phosphatic fertilizer on the Motukarara, Chertsey and Craigieburn soil sites. These results tend to confirm the experience of Harris et al. (1966) who found heavy annual applications of phosphatic fertilizer to be associated with an increased occurrence of volunteer species in an irrigated ten-year-old lucerne crop.

It is widely believed that the establishment of volunteer species in the lucerne crop is a prime cause of its deterioration and diminished productivity (Blair, 1965). In view of the enhanced growth of some volunteer species that may occur in the lucerne crop where phosphatic fertilizer has been applied, one is forced to consider whether the practice of applying phosphatic fertilizer is detrimental to the lucerne crop and whether it should be discontinued in order to minimize growth of volunteer species and prolong the productive life of the crop,

There is evidence to suggest that the belief that the establishment of volunteer species in the lucerne crop is an important cause of its deterioration and diminished productivity is not well founded. O'Connor and Vartha (1968) concluded that the higher incidence of weeds in frequently harvested lucerne is the outcome of reduced competition by lucerne. In South Otago, applications of potassic fertilizer to lucerne established on a potassiumdeficient site caused lucerne yields $85 \%$ greater than those resulting from the removal of volunteer grasses by application of a suitable herbicide (Stephen, 1964). In the experiments described in this paper, notwithstanding the more vigorous growth of some volunteers, five-year-old lucerne grew more vigorously and produced significantly higher yields of herbage where applications of phosphatic fertilizer had been made. These experiences suggest that some volunteer species which establish in the lucerne crop have comparatively little effect on the growth of lucerne and that volunteer species occur more frequently in lucerne crops where the vigour of the lucerne has been limited by environmental factors other than the presence of volunteers. It is suggested, therefore, that the presence of volunteer species in the lucerne crop is a symptom of poor lucerne growth rather than a cause of poor lucerne growth.

In the fertilizer experiments described, five-year-old lucerne produced upwards of $40 \%$ more herbage where topdressed with a phosphatic fertilizer. Many of the soils used in Canterbury for lucerne cultivation have low phosphorus levels (Kear et al., 1967). Responses to applied phosphatic fertilizer similar to those obtained in the experi- 
ments described are likely to occur under commercial conditions where the farmer, in spite of possible increases in the growth of volunteers, cannot afford to forgo the advantages of the extra fodder produced.

The removal of lucerne herbage as hay or silage exhausts soil reserves of plant nutrients (Dale, 1967). Harris et al. (1966) reported that deficiencies of potassium and molybdenum developed after lucerne hay had been harvested for several years from an area of Lismore stony silt loam to which only lime, phosphatic and sulphatic fertilizers had been applied. Where applications of phosphatic fertilizer cause more vigorous lucerne growth, the exhaustion of soil reserves of other plant nutrients, especially potassium, is likely to be accelerated as a result of the removal of the greater quantities of herbage produced. A reduction in the quantity of phosphatic fertilizer applied to lucerne established on a phosphate-deficient soil may tend to delay the development of induced deficiencies of other nutrients. However, induced deficiencies would be better corrected by applying fertilizers containing the required nutrients rather than by limiting lucerne growth by withholding phosphatic fertilizer.

It is concluded therefore that, if maximum yields of herbage are sought from lucerne established on phosphatedeficient Canterbury soils, the practice of applying phosphatic and other fertilizers should be neither discontinued nor reduced to a level below that necessary for maximum lucerne production.

\section{ACKNOWLEDGEMENTS}

The author thanks G. Nurse, Greenpark, K. R. Taylor, Te Pirita, W. J. Doyle, Te Pirita, and G. C. Urquhart, Cass, for providing experimental sites; T. N. Kemp, B. W. Todd, and D. Stanley for considerable technical assistance; the staff of the Herbage Laboratory, Winchmore Irrigation Research Station, for dry matter percentage determinations and botanical dissections of herbage; J. L. Grigg, Invermay Agricultural Research Centre, Mosgiel, for chemical analyses of soil; the staff of the Biometrics Section, Department of Agriculture, for statistical analyses and P. B. Lynch, D. Joblin, J. A. Douglas and F. C. Allen for valuable criticism and advice.

\section{REFERENCES}

Allen, F. C., 1967: In The Lucerne Crop, R. H. M. Langer (ed.), A. H. $\therefore \quad \&$ A. W. Reed, Wellington. p. 221. 
Anon., 1958: Lucerne. N.Z. Dep. Agric. Bull. 155.

Blair. I. D., 1965: Cant. Chamber Comm. Agric. Bull. 434. 1968: Proc. 2Ist N.Z. Weed \& Pest Control Conf.: 38.

Dale, W. R., 1967: In The Lucerne Crop, R. H. M. Langer (ed.), A. H. \& A. W. Reed, Wellington. p. 134.

Harris, P. B.; Lobb, W. R., 1964: Proc. 14th Lincoln Coll. Fmrs' Conf.: 34.

Harris, P. B.; McNaught, K. J.; Lynch, P. B., 1966: N.Z. Jl agric. Res., 9: 653.

Kear, B. S.; Gibbs, H. S.; Miller, R. B., 1967: Soils of the downs and plains, Canterbury and North Otago, New Zealand. Soil Bur, Bull. 14.

Keoghan, J. M., 1967: In The Lucerne Crop, R. H. M. Langer (ed. j, A. H. \& A. W. Reed, Wellington. p. 119.

Lobb, W. R., 1967: In The Lucerne Crop, R. H. M. Langer (ed.), A. H. \& A. W. Reed, Wellington. p. 150.

1969: Proc. 22nd N.Z. Weed \& Pest Control Conf.: 105.

O'Connor, K. F.; Vartha, E. W., 1968: Proc. 21st N.Z. Weed \& Pest Control Conf.: 54.

Stephen, R. C., 1964: N.Z. Jl agric., 108: 433.

Sewell, T. G., 1960: Proc. 13th N.Z.' Weed \& Pest Control Conf.: 90.

Ward, F. E., 1921: N.Z. Jl agric., 23: 363.

\section{DISCUSSION}

Smith (U.S.A.) questioned whether maximum growth would be obtained from lucerne in New Nealand at $\mathrm{pH}$ levels of only about 5.9 to 6.1. Research in the States, and particularly at Wisconsin, showed that $\mathrm{pH}$ levels could not be less than 6.5 to 7.0 in the first seven or eight inches of the soil. Below these levels they could not get lucerne to grow. He knew of cases where up to eight tons of lime per acre in two separate dressings had been worked into the soil to correct the $\mathrm{pH}$ level. Stephen replied that they were obtaining most growth at the stated $\mathrm{pH}$ levels. In another experiment $\frac{1}{2}$ ton, lime plus molybdenum was giving as good production as two tons of lime, with the respective $\mathrm{pHs}$ of 5.8 and 6.3. O'Connor was not satisfied that surface lime application was sufficient to overcome low $\mathrm{pH}$, but Stephen said that lucerne had produced $25.000 \mathrm{lb}$ DM under $\mathrm{pH}$ of 5.9 at the surface. The $\mathrm{pH}$ below 6 in. was not much lower. Others had noticed no advantage from working in lime. Smith maintained that $\mathrm{pH} 6.5$ to 7 throughout the top 7 in. of the soil was necessary for maximum growth. Smetham and Langer both commented that lime was important for nodulation and the latter stressed the importance of distribution through the soil. Walker commented that, when he came to New Zealand from the U.K. 18 years ago, he had been astonished at the apparent disregard for $\mathrm{pH}$ here as compared with Britain, where experience had indicated that a much higher level was desirable. He had concluded that there was a lot of tradition in what they had been taught. In New Zealand, 
molybdenum had been shown to be critical. He also felt that aluminium and manganese toxicity, as well as host/rhizobia relationships, would be most important. Perhaps lip service was being paid to lime without their really knowing what it was doing. Langer asked what would be the effect of fertilizer on weed ingress in a non-vigorous lucerne stand and the effect of fertilizer on a weedinfested stand. Stephen stated that withholding phosphate on a phosphate-deficient soil would reduce the vigour of the lucerne and increase weed content. With the application of phosphate the result would be more lucerne and less weeds and other species. Thus, if weeds were present because of fertilizer deficiency, this could be corrected by applying fertilizer. However, if, for instance, poor drainage was the cause of weed infestation, then fertilizer would not correct the position. 